\title{
SURGICAL CORRECTION OF SEVERE AND FIXED CHIN-ON-CHEST DEFORMITY
}

\section{CORREÇÃO CIRÚRGICA DE GRAVE DEFORMIDADE FIXA DO TIPO QUEIXO-NO-PEITO}

\author{
Raphael Martus Marcon ${ }^{1}$, Allan Hiroshi de Araujo Ono ${ }^{1}$, Flávio Gerardo Benites Zelada ${ }^{1}$, Alexandre Fogaça Cristante ${ }^{1}$, \\ Tarcisio Eloy Pessoa Barros Filho ${ }^{1}$
}

1. Universidade de São Paulo, Faculdade de Medicina, Hospital das Clínicas (IOT-HCFMUSP), Instituto de Ortopedia e Traumatologia, Laboratory of Medical Investigation, Spine Surgery Division, São Paulo, SP, Brazil.

\begin{abstract}
Objective: To describe a successful surgical treatment for the challenging severe and fixed chin-on-chest deformity due to isolated neck extensor myopathy (INEM). Background data: INEM is an idiopathic cause of dropped head syndrome (DHS) that results in severe cervicothoracic kyphosis, defined as chin-on-chest deformity. The existing literature on surgical management is limited, with outcomes ranging from poor to excellent. INEM may present to the spinal surgeon for consideration of surgical management. Methods: The authors present a technique that uses a staged posterior and anterior approach combined with osteotomies and corpectomy to correct the severe and fixed deformity. A state of the art anterior and posterior instrumentation system was used. Results: At the three-months follow-up, there was good deformity correction and the patient's satisfaction was high, with no neurological deterioration occurring. Conclusions: The technique illustrated in this study represents a successful option to treat this debilitating deformity. More evidence is needed to set up a definitive algorithm for the management of this condition. Level of evidence IV, Case Report.
\end{abstract}

Keywords: Surgical procedures operative. Spinal diseases. Cervical vertebrae. Osteotomy. Decompression, surgical.

\section{RESUMO}

Objetivo: Descrever o tratamento cirúrgico de deformidade desafiadora, grave, de queixo-no-peito devida a miopatia isolada do extensor do pescoço. Contexto: A miopatia isolada do extensor do pescoço é uma causa, idiopática, da síndrome da cabeça caída. Resulta em grave cifose cérvico-torácica, chamada de "deformidade queixo-no-peito". A literatura sobre o tratamento cirúrgico da deformidade é limitada, com resultados de pobres a excelentes. A miopatia isolada do extensor do pescoço pode ser considerada para tratamento cirúrgico. Métodos: Os autores apresentam a técnica, que usa vias anterior e posterior em estágios, combinadas com osteotomias e corpectomia para corrigir a deformidade, grave e fixa. A melhor instrumentação e sistemas para abordagem anterior e posterior foram utilizadas. Resultados: Após três meses de follow-up, houve boa correção da deformidade e a satisfação da paciente foi alta, sem deterioração do status neurológico. Conclusões: A técnica se mostrou boa opção para tratamento de sucesso desta deformidade. Mais evidências são necessárias para estabelecer um algoritmo definitivo para a condução dessa deformidade. Nível de evidência IV, Relato de Caso.

Descritores: Procedimentos cirúrgicos operatórios. Doenças da coluna vertebral. Vértebras cervicais. Osteotomia. Descompressão cirúrgica.

Citation: Marcon RM, Ono AHA, Zelada FGB, Cristante AF, Barros Filho TEP. Surgical correction of severe and fixed chin-on-chest deformity. Acta Ortop Bras. [online]. 2018;26(6):415-7. Available from URL: http://www.scielo.br/aob.

\section{INTRODUCTION}

Dropped head syndrome is a disease characterized by a severe neck extensor muscle weakness, resulting in a chin-on-chest deformity in the sitting or standing position, correctable by passive neck extension, isolated or associated to neuromuscular diseases., ${ }^{1,2}$ Extreme weakness in the paraspinal muscles, with absence of a neuromuscular disease or specific abnormalities in eletroneuromiography and muscle biopsy is termed isolated neck extensor myopathy (INEM). 3,4 The resulting chin-on-chest deformity starts as a flexible deformity, which becomes rigid as a consequence of prolonged flexion and calcification of the anterior longitudinal ligament. ${ }^{4}$

Treatment results with physical therapy, massage and acupuncture are inconsistent in cases series reports, 2,5,6 and most studies show little improvement with non-surgical management. ${ }^{3,5,7}$ A collar can help the patient to maintain horizontal gaze and eye contact, and facilitate activities of daily living, although there are problems with compliance to the collar, skin pressure lesions and possible worsening of muscular weakness with prolonged use., ${ }^{2,6}$ The goal of the surgical

All authors declare no potential conflict of interest related to this article.

Work conducted at the Laboratory of Medical Investigation, Spine Surgery Division, Instituto de Ortopedia e Traumatologia, Hospital das Clínicas da Faculdade de Medicina da Universidade de São Paulo (IOT-HCFMUSP), São Paulo, Brazil.

Correspondence: Alexandre Fogaça Cristante. Rua Dr. Ovídio Pires de Matos, 333, São Paulo, SP, Brazil. 04018-001. aacristante@uol.com.br 
management of dropped-head syndrome is to improve quality of life by correcting the deformity, decompressing of neural elements when necessary and promoting long-term stabilization, ${ }^{8}$ reating patients for whom conservative measures failed or for those who do not have treatable conditions as a cause for the dropped-head. ${ }^{9,10}$

\section{CASE REPORT}

Our patient is a 56-years-old female referred to our hospital after 12 years of symptoms and conservative treatment in the northeast of the country. She complained of progressive drop of the head with incapability to extend neck or to look forward, and denied any serious trauma history or previous diseases. Previous medical records were not available.

She reported that symptoms initiated insidiously, with weakness of the hind neck muscles, with mild cervical pain. After three years, she was incapable to extend the head. In her home region, she was then treated with physiotherapy. By the time she was referred to our specialized center, she had had several falls from her own height without any major injuries or detected fractures. The deformity had become rigid, and she was considered inoperable.

The head was totally supported by her chest, causing face deformity of left cheek and ear. The clinical aspect of the patient is shown in Figure 1. Even with a passive maneuver in supine position, the head could not be extended, and the anterior left sternocleidomastoid seemed
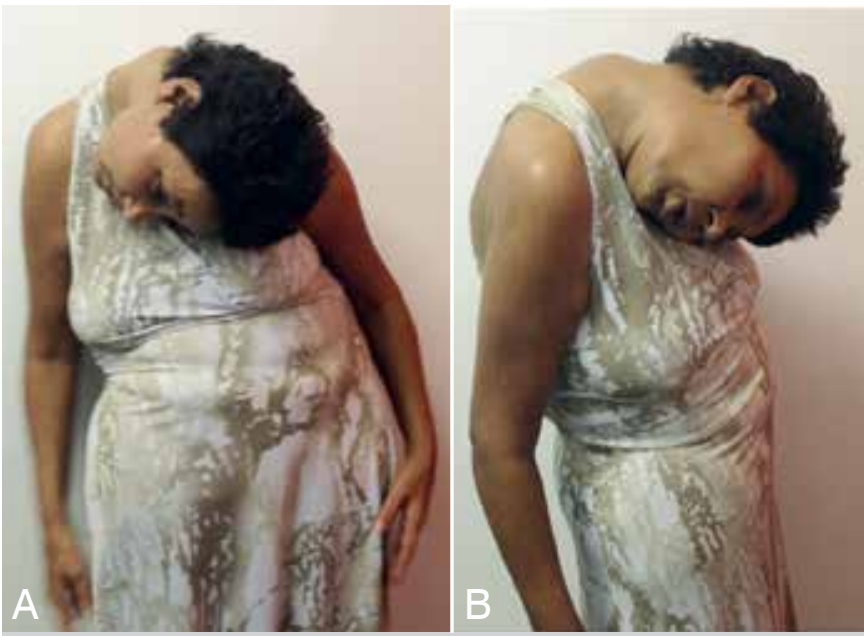

Figure 1. Clinical photos of the patient showing the fixed chin-on-chest deformity with the head rotated to the right, before surgery. contracted. Superior and lower limbs strength were grade V (normal); sensitivity was normal and symmetric in torso and limbs. No pathologic reflex or signs of myelopathy were found. The patient could barely walk leaning on the walls and furniture, and she refused to use a cane or crutches. Feeding was possible only in the supine position. Investigation was initiated with rheumatology, genetics and neurology specialists. Ankylosing spondylitis and rheumatoid arthritis were discarded by serum exams. Head MRI was normal, and the neurology team also discarded Parkinson's disease, lateral amyotrophic sclerosis and myasthenia gravis, as well as tumors and psychiatric diseases. The patient had no diabetes or hypertension, and she was not a smoker. She was then diagnosed with isolated neck extensor myopathy (INEM), and surgery was planned and patient signed Free and Informed Consent Form for surgery and publication of this case report. The approval of the Research Ethics Committee is waived for case reports in our institution.

Lateral mass screws were placed at C2, C3 and C4 and pedicle screws at T1, T2 and T3. The posterior elements of C5, C6 and C7 (lamina, facet joints and pedicles) were fully resected. After extensive release, the head started to move, which caused a decrease in the motor evoked potentials (MEP) of about $30 \%$. In that moment, one of assistants, outside the sterile field, started reduction, by gently tractioning the head; this recovered the initial MEP results, and great correction was achieved. Two rods were molded and fixed and one autograft from the resected local bone was placed in the fusion area. Patient was admitted to the intensive care unit (ICU) (Figure 2). After one week, anterior corpectomy of $\mathrm{C} 5$ and $\mathrm{C} 6$ with autogenous iliac crest bone graft with anterior plating from $\mathrm{C} 4$ to $\mathrm{C}$, with placement of mesh cage, was performed (Figure 3). After three days, the patient was discharged from the ICU and started rehabilitation using a cervicothoracic brace. She was able to walk by the fourth postoperative day. The patient went home 20 days after the second procedure, in use of a Philadelphia brace. The brace had to be discontinued after four weeks due to occipital ulceration, and a soft collar was recommended by the second postoperative month. The patient was still happy with the procedure in the third month of follow-up, but she complains about head rotation, that was not fully corrected. Even so, she would undergo surgery again if necessary. Nowadays she walks independently without any support (Figure 4).

\section{DISCUSSION}

A challenge of the correction of chin-on-chest deformity is choosing the number of levels to be instrumented. Sharan et al. ${ }^{4}$ advocate a posterior instrumented fusion from $\mathrm{C} 2$ to $\mathrm{T} 3$, T4, or T5. This procedure has the advantage of retaining some rotation as well as flexion and extension
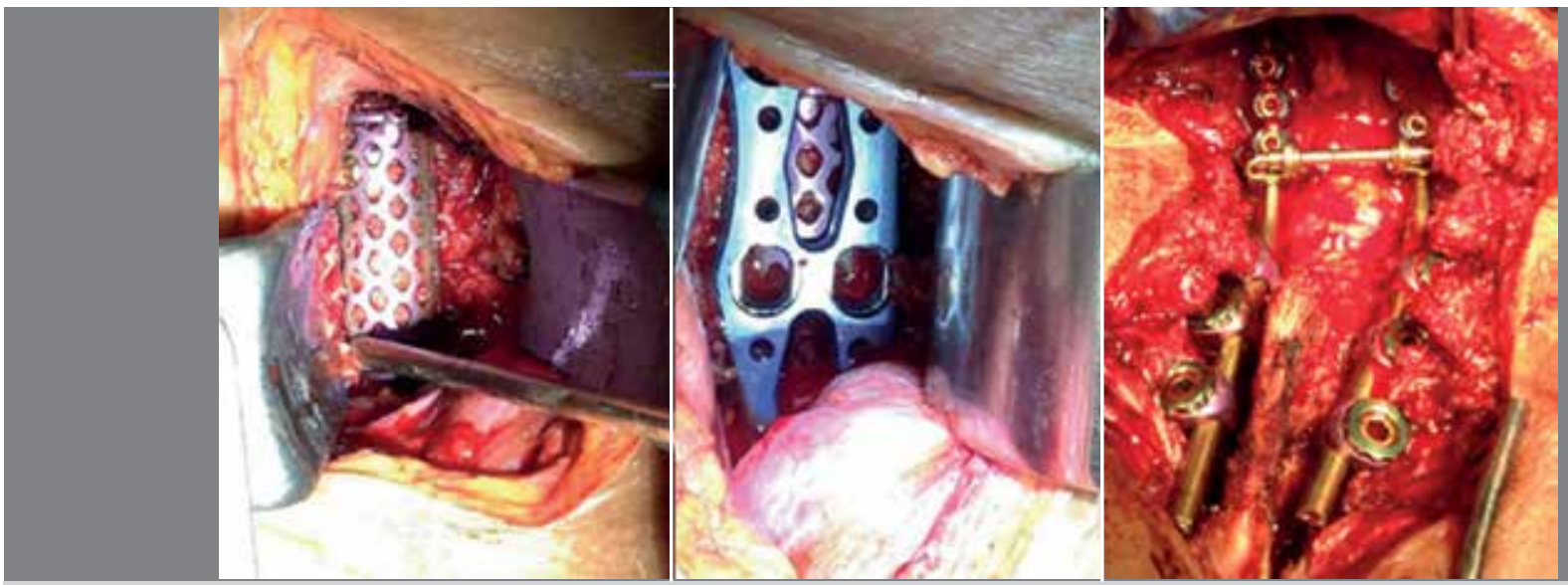

Figure 2. Surgical procedure. 


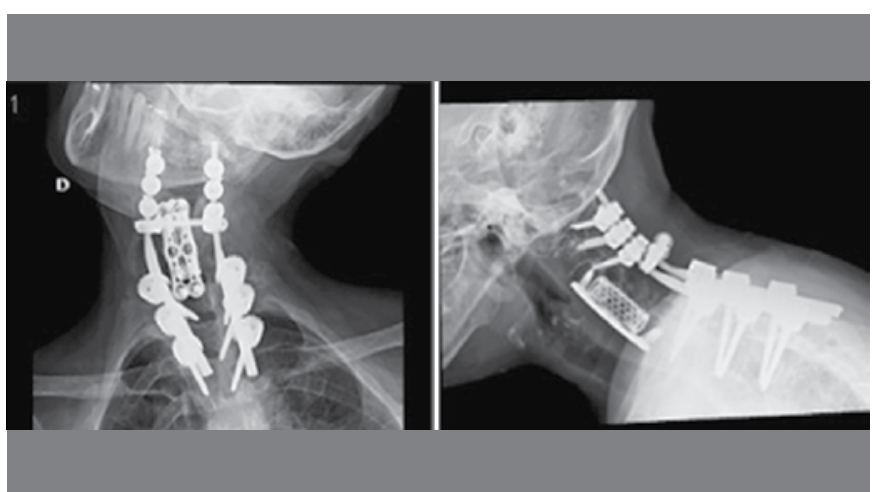

Figure 3. Radiographic images after surgery.

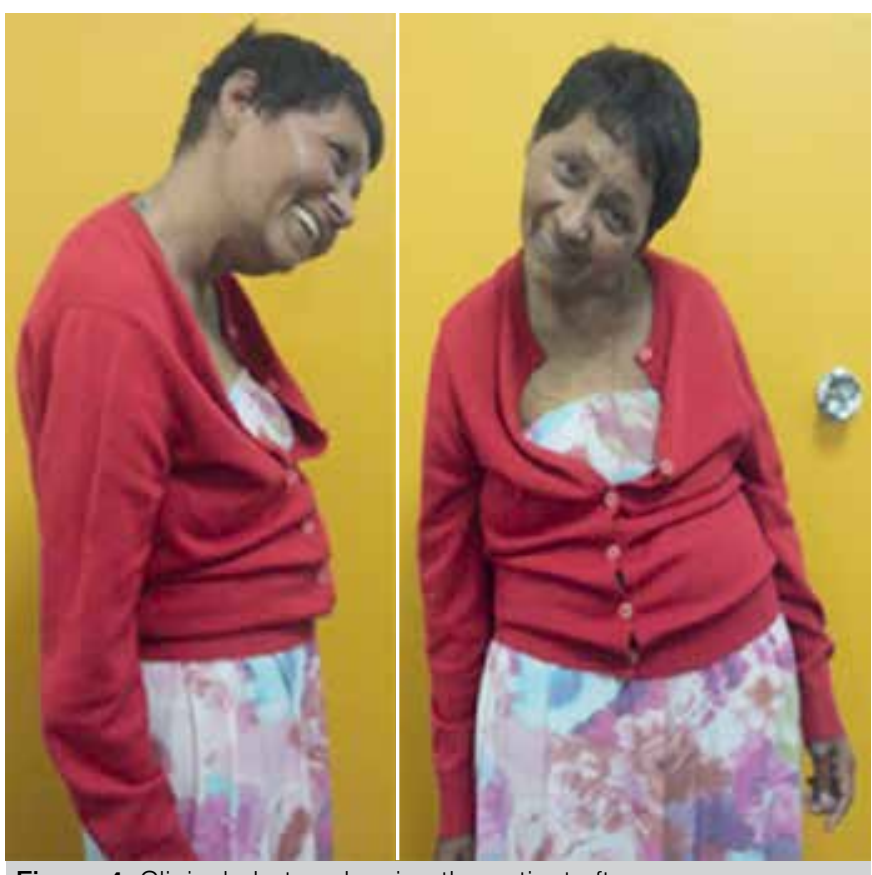

Figure 4. Clinical photos showing the patient after surgery. at the upper cervical levels. Although the deformity usually starts at C4, the authors recommend starting the construct at $\mathrm{C} 2$ in an effort to avoid long-term failure. We performed a Grade 7 osteotomy, ${ }^{11}$ i.e., resection of one or more entire vertebral bodies discs and uncovertebral joints, posterior lamina and facets. In our case, no correction was possible with positioning or tractioning the head; reduction was only possible after removal of all posterior elements of three vertebrae, C5, C6 and C7. Like in most cases reported, we fixed vertebrae from C2 to T3. The anterior approach did not improve correction but promoted stability and decompression of neural elements.

The literature on the surgical management on this uncommon condition is very limited, with the largest series describing only nine patients, being the only report on long-term results. ${ }^{7}$ The average follow up was 6 years, and only four cases were primary INEM, the others had undergone local radiation therapy. All cases were fixed from $\mathrm{C} 2$ to thoracic levels ranging from $\mathrm{T} 1$ to $\mathrm{T5}{ }^{7}$ Most patients experienced improved neck positioning and elimination of pain while standing and walking and reported marked improvement in quality of life and activity level. 2,7

Another study with 26 patients with chin-on-chest deformity secondary to ankylosing spondylitis also showed good results in the long term, with improvement in quality of life and achieving fusion, but with one death postoperatively and six neurologic complications (no quadriplegia). ${ }^{12}$ The most reported complications in those series were pneumonia and skin ulcer caused by the prolonged use of orthosis; pseudoarthrosis and implant failure were also reported. Our patient also had skin ulcer, which caused orthosis discontinuation, without loss of correction or implant failure.

\section{CONCLUSION}

We reported a case of dropped head syndrome with severe and fixed chin-on-chest deformity attributed to INEM, which poses a surgical challenge. Surgical issues to consider involves the optimal timing to intervention, the choice of approach (anterior X posterior X 360), and the levels for decompression and fusion. We consider that neurologic complications can be avoided in the moment of release of posterior elements by using a provisory rod or by an assistant holding the head. Although there is no formal standard care for this condition, appropriate surgical treatment of this patient was possible following the principles for surgical spine treatment: decompression of neural elements, if necessary; correction of deformity and stabilization.

AUTHORS' CONTRIBUTIONS: Each author contributed individually and significantly to the development of the manuscript. AHAO (0000-0003-2112-4654)* and FGBZ (0000-0002-7659-8315)* were the main contributors in writing the manuscript. RMM (0000-0001-59585646)* and AFC (0000-0002-7797-5274)* underwent surgery, monitored patient and collected clinical data. TEPBF (0000-0002-7969-7845)* contributed with the intellectual concept of the study. *ORCID (Open Researcher and Contributor ID).

\section{REFERENCES}

1. Suarez GA, Kelly JJ. The dropped head syndrome. Neurology. 1992 Aug 1;42(8):1625-1625

2. Petheram TGBs (Hons), Hourigan PGM, Emran IM, Weatherley CR. Dropped Head Syndrome: A Case Series and Literature Review. [Miscellaneous Article]. Spine January 1 2008. 2008;33(1):47-51.

3. Kastrup A, Gdynia H-J, Nägele T, Riecker A. Dropped-head syndrome due to steroid responsive focal myositis: a case report and review of the literature. J Neurol Sci. 2008 Apr 15;267(1-2):162-5.

4. Sharan AD, Kaye D, Malveaux WMSC, Riew KD. Dropped Head Syndrome: Etiology and Management. J Am Acad Orthop Surg. 2012 Dec 1;20(12):766-74.

5. Martin AR, Reddy R, Fehlings MG. Dropped head syndrome: diagnosis and management. Evid-Based Spine-Care J. 2011 May;2(2):41-7.

6. Macé Y, Yahia M, Rannou F, Lefevre-Colau M, Poiraudeau S, Revel M. [Value of intensive rehabilitation in fixed dropped head syndrome]. In 2005. p. 207-11.

7. Gerling MC, Bohlman HH. Dropped head deformity due to cervical myopathy: surgical treatment outcomes and complications spanning twenty years. Spine. 2008;33(20):E739-45.

8. Katz JS, Wolfe GI, Burns DK, Bryan WW, Fleckenstein JL, Barohn RJ. Isolated neck extensor myopathy A common cause of dropped head syndrome. Neurology. 1996 Apr 1;46(4):917-21.

9. Larsen H, Bogaard PW, Oppel L. A case of isolated neck extensor myopathy responding favorably to immunotherapy. J Clin Neuromuscul Dis. 2013;15(2):73-6.

10. Biran I, Cohen O, Diment J, Peyser A, Bahnof R, Steiner I. Focal, steroid responsive myositis causing dropped head syndrome. Muscle Nerve. 1999;22(6):769-71.

11. Ames CP, Smith JS, Scheer JK, Shaffrey CI, Lafage V, Deviren V, et al. A standardized nomenclature for cervical spine soft-tissue release and osteotomy for deformity correction. J Neurosurg Spine. 2013 Jul 5;19(3):269-78.

12. Belanger TA, MilamIV RA, Roh JS, Bohlman HH. Cervicothoracic extension osteotomy for chin-on-chest deformity in ankylosing spondylitis. J Bone Jt Surg. 2005;87(8):1732-8. 